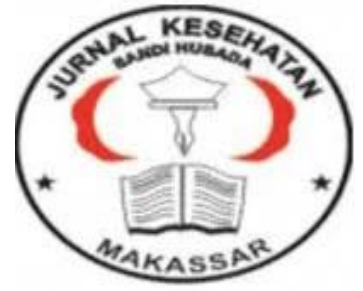

Jurnal Ilmiah Kesehatan Sandi Husada

hhttps://akper-sandikarsa.e-journal.id/JIKSH

Volume 9, Nomor 2, Desember 2020, pp 908-915

p-ISSN: 2354-6093 dan e-ISSN: 2654-4563

DOI: $10.35816 /$ jiskh.v10i2.431

\title{
Potensi Manfaat Kardioprotektif dari Minyak Zaitun
}

\section{Literatur Riview}

Potential Cardioprotective Benefits of Olive Oil

\section{Anisa Prima Justica Mustikyantoro}

Fakultas Kedokteran, Universitas Lampung

\section{Artikel info}

\section{Artikel history:}

Received; Juli 2020

Revised: Agustus 2020

Accepted; September 2020

\section{Abstract}

Cardiovascular disease is the leading cause of death in the world and the two main risk factors for its development are aging and diet. Diet plays a decisive role in health maintenance and disease prevention. Meanwhile, olive oil is known to provide beneficial effects on hypertension and the prevention of cardiovascular disease with various important components in it. There are two types of olive oil depending on the production mechanism, namely extra virgin olive oil (EVOO) and refined olive oil (ROO). This literature study aimed to assess the association between olive oil intake and the risk of cardiovascular disease and the potential cardioprotective benefits of olive oil. Method. This research is a literature review involving 18 literature sources from 1 national journal and 17 international journals. Result. Several studies have significantly demonstrated the cardioprotective, antithrombotic, and anti-inflammatory properties of olive oil from both the major and minor components of olive oil. Conclusion. Consistent food intake with olive oil can provide a cardioprotective effect from various important components in it, as a prevention of cardiovascular disease.

\section{Abstrak}

Penyakit kardiovaskular menjadi penyebab kematian terbanyak di dunia dan dua faktor risiko utama perkembangannya adalah penuaan dan pola makan. Diet memainkan peran penentu dalam pemeliharaan kesehatan dan pencegahan penyakit. Sementara itu, minyak zaitun diketahui dapat memberikan efek menguntungkan pada keadaan hipertensi dan pencegahan penyakit kardiovaskular dengan berbagai komponen penting didalamnya. Terdapat dua jenis minyak zaitun tergantung pada mekanisme produksinya, yaitu minyak zaitun extra virgin (extra virgin olive oil / EVOO) dan minyak zaitun murni (refined olive oil/ ROO). Tujuan dari studi literatur ini adalah untuk menilai hubungan antara asupan minyak 
zaitun dan risiko penyakit kardiovaskular serta potensi mafaat kardioprotektif dari minyak zaitun. Metode; penelitian ini merupakan literature review yang melibatkan sumber pustaka sebanyak 18 pustaka yang berasal dari 1 jurnal nasional dan 17 jurnal internasional. Hasil. Beberapa penelitian secara signifikan menunjukkan sifat kardioprotektif, antitrombotik dan antiinflamasi dari minyak zaitun baik dari komponen mayor maupun minor minyak zaitun. Kesimpulan. Asupan makanan dengan minyak zaitun secara konsisten dapat memberikan efek kardioprotektif dari berbagai komponen penting didalamnya, sebagai pencegahan penyakit kardiovaskular.

Keywords:

Antioksidan;

Kardioprotektif;

Minyak zaitun;

Nutraceutical.
Corresponding author: Email: anisaprima.ap@gmail.com

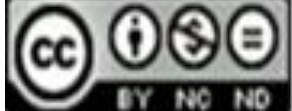

artikel dengan akses terbuka dibawah lisensi CC BY -4.0

\section{Pendahuluan}

Kebiasaan merokok, mengkonsumsi alkohol, pola makan yang tidak sehat dan / atau kurangnya olahraga merupakan beberapa faktor yang dapat menyebabkan peningkatan risiko kematian akibat penyakit kardiovaskular (cardiovascular disease/CVD) pada usia muda dan paruh baya. Selain itu, penyakit ini juga menjadi penyebab utama morbiditas dan kecacatan. Penyakit kardiovaskular merupakan masalah kesehatan utama di seluruh dunia dan pengaruhnya terhadap status kesehatan dan kesejahteraan telah menjadi perhatian di banyak penelitian. Beberapa penyakit kardiovaskular yang sering terjadi adalah hipertensi, penyakit jantung iskemik atau gagal jantung, dan juga terkait dengan gangguan metabolik seperti dislipidemia dan diabetes. Selain itu, kualitas hidup dapat terpengaruh karena berbagai hambatan dapat muncul dari penyakit ini seperti depresi, insomnia, atau gangguan kognitif (Tejada et al., 2016)

Penyakit kardiovaskular bertanggung jawab atas 17,5 juta kematian di seluruh dunia pada tahun 2012 dengan sebanyak 46,2\% kematian akibat penyakit tidak menular (PTM). Faktanya, 37\% dari PTM ini disebabkan oleh penyakit kardiovaskular pada usia di bawah 70 tahun. Pada tahun 2012, penyakit jantung iskemik (7,4 juta kematian) dan stroke $(6,7$ juta) adalah penyebab utama penurunan harapan hidup akibat kematian dini. Penyakit kardiovaskular dapat dicegah jika individu berisiko tinggi diidentifikasi lebih awal. Dinyatakan bahwa modifikasi faktor risiko yang terkait dengan penyakit kardiovaskuler dapat bermanfaat dan memiliki tindakan pencegahan pada penyakit ini (Tejada et al., 2016). Selama dekade terakhir, pendekatan nutraceutical telah diusulkan untuk melawan fenomena penyebaran penyakit kardiovaskular. Istilah nutraceutical, berasal dari gabungan kata 'nutrition' yang berarti nutrisi dan 'pharmaceuticals' yang berarti farmasi, diciptakan oleh De Felice pada tahun 1989 untuk menunjukkan efek menguntungkan pada kesehatan manusia dari zat yang terkandung dalam makanan (Kalra, 2003). Pendekatan nutraceutical memusatkan perhatian pada produk aktif biologis yang terkandung dalam makanan (Loffredo et al., 2017).

Minyak zaitun (Olea europaea L.) adalah spesies tumbuhan yang tersebar di Asia Timur dan Selatan sampai ke basin Mediterania, Makaronesia serta Afrika Timur dan Selatan (Besnard et al., 2002). Terdapat dua jenis minyak zaitun tergantung pada mekanisme 
produksinya, yaitu minyak zaitun extra virgin (extra virgin olive oil / EVOO) dan minyak zaitun murni (refined olive oil/ RO0). Kedua jenis minyak zaitun tersebut memiliki komposisi yang sama pada asam lemak tak jenuh tunggal (monounsaturated fatty acids/ MUFAs), terutama asam oleat, namun berbeda pada kandungan komponen minornya. Sekitar 98-99\% dari total berat EVOO diwakili oleh MUFAs. Sisanya sebanyak 1-2\% berupa komponen minor, diklasifikasikan sebagai senyawa unsaponifable (squalene, sitosterol, triterpen, pigmen, dll.) serta senyawa hidrofilik (tokoferol, senyawa fenolik). EVOO diperoleh melalui proses fisik, yaitu dengan menghancurkan dan menekan buah zaitun. Sebaliknya, ROO melewati mekanisme ekstraksi kimia, seperti refinement, yang menghilangkan sebagian besar komponen minor (Yubero-Serrano et al., 2019). Sifat menguntungkan dari minyak zaitun, termasuk yang efek kardioprotektif, telah lama dikaitkan dengan kandungan MUFAs yang tinggi. Namun, beberapa penelitian juga menyoroti efek manfaat antioksidan dari komponen minor (terutama senyawa fenolik) dari EVOO mengenai pengurangan risiko trombotik, peradangan, aterosklerosis, stres oksidatif dan kanker (Summerhill et al., 2018). Sebagian besar penelitian sebelumnya ada yang tidak membuat perbedaan di antara varietas minyak zaitun yang berbeda (EVOO atau ROO) ketika menyelidiki efek konsumsi minyak zaitun terhadap kesehatan, meskipun terdapat perbedaan kandungan komponen bioaktif minor. Telah dilaporkan bahwa minyak zaitun, terutama EVOO memiliki efek menguntungkan pada faktor risiko kardiovaskular, seperti koagulasi, agregasi platelet, lipid, fungsi endotel dan peradangan (Rus et al., 2020). Oleh karena itu, tujuan dari literature review ini adalah untuk mengetahui potensi manfaat kardioprotektif dari minyak zaitun karena minyak zaitun sangat mudah didapatkan di Indonesia sehingga dapat memberikan informasi bermanfaat bagi masyarakat luas.

\section{Metode}

Metode yang digunakan adalah studi literatur yang diambil dari beberapa jurnal nasional maupun internasional dan artikel ahli yang diakses online. Metode ini berupaya meringkas pemahaman kondisi terkini mengenai suatu topik. Studi literatur ini menyajikan materi yang telah diterbitkan sebelumnya dan menganalisis suatu fakta baru Penelusuran sumber pustaka dalam artikel ini melalui database PubMed dan Google Scholar. Sumber pustaka yang digunakan dalam penyusunan melibatkan 17 sumber pustaka yang terdiri dari 1 jurnal nasional dan 19 jurnal internasional. Pemilihan artikel sumber pustaka dilakukan dengan melakukan peninjauan pada judul, abstrak dan hasil yang membahas potensi manfaat kardioprotektif dari minyak zaitun.

\section{Hasil Dan Pembahasan}

Di antara strategi nutrisi, minyak zaitun extra virgin (EVOO) telah diusulkan sebagai agen kardioprotektif yang baik. Sebuah tinjauan sistematis dan meta-analisis telah mengevaluasi efek minyak zaitun polifenol tinggi versus rendah pada faktor risiko penyakit kardiovaskular dalam uji klinis. Ditemukan beberapa bukti perbaikan penanda inflamasi dan tekanan darah, terutama minyak polifenol tinggi yang memberikan beberapa manfaat kardiovaskular (George et al., 2019; Vazquez et al., 2019).

Pada penelitian Hadju et al. (2012) didapatkan efek yang menguntungkan dari suplementasi EVOO dalam bentuk kapsul dengan dosis 4,8 gr per hari pada subjek hiperkolesterolemia ringan. Ditemukan perbaikan kadar kolesterol total dialami setelah konsumsi minyak zaitun extra virgin selama 6 minggu ( $p=0,017)$ (Hadju et al., 2012). Dalam penelitian lain oleh Wongwarawipat et al. (2017) ditemukan bahwa konsumsi EVOO dikaitkan dengan penurunan biomarker inflamasi dan molekul yang terlibat dalam 
aterosklerosis maupun kejadian penyakit kardiovaskular, mortalitas serta komplikasi lain seperti gagal jantung dan fibrilasi atrium. Selain itu, efek anti-inflamasi dan kardioprotektif EVOO ini sebagian besar disebabkan oleh kandungan molekul polifenol yang tinggi (Wongwarawipat et al., 2017). Pada individu dengan disfungsi endotel, Widmer et al. (2015) mengevaluasi efek minyak zaitun (340 mg / kg polifenol total) dan minyak zaitun yang diperkaya dengan epigallocatechin 3-gallate (EGCG) yaitu katekin yang secara alami ditemukan dalam teh hijau $(300 \mathrm{mg} / \mathrm{kg}$ polifenol total $+280 \mathrm{mg} / \mathrm{Kg}$ EGCG) tentang mediator inflamasi. Pada penelitian tersebut tidak ditemukan perbedaan antara kelompok minyak zaitun dengan minyak zaitun + EGCG, tetapi disimpulkan bahwa suplementasi minyak zaitun untuk diet biasa selama 4 bulan memiliki efek positif pada pengurangan molekul adhesi sel (sICAM-1), trombosit, monosit, dan limfosit yang terlibat dalam proses peradangan (Widmer et al., 2015).

Penelitian efek kardioprotektif juga dilakukan oleh Rus et al. (2020) pada sampel darah wanita dengan fibromialgia yang mengonsumsi $50 \mathrm{~mL}$ minyak zaitun organik setiap hari selama 3 minggu, sebelumnya pasien diacak menjadi dua kelompok, sebanyak 15 wanita mengonsumsi minyak zaitun extra virgin (EV00) dan 15 wanita yang mengonsumsi minyak zaitun murni (ROO). Penanda risiko kardiovaskular diukur pada awal (pengukuran awal) dan setelah konsumsi minyak zaitun (setelah pengukuran). Jumlah sel darah merah dan laju sedimentasi eritrosit (LED) menurun secara signifikan setelah pengobatan pada kelompok EVOO ( $p$ $<0,05)$. Konsumsi R00 meningkatkan volume platelet rata-rata dan mengurangi lebar distribusi platelet (platelet distribution width/PDW), rasio neutrofil ke limfosit, LED dan fibrinogen $(\mathrm{p}<0,05)$. Perbedaan yang signifikan ditemukan pada pra dan pasca perlakuan antara kelompok EVOO dan ROO untuk kortisol dan PDW ( $p<0,05)$. Hasil tersebut menunjukkan bahwa konsumsi minyak zaitun mungkin memiliki sifat antitrombotik dan antiinflamasi pada pasien fibromialgia. Baik EVOO dan ROO mungkin berguna sebagai adjuvan untuk pencegahan dan / atau pengobatan gangguan kardiovaskular pada pasien ini (Rus et al., 2020).

Penelitian lain oleh vazques (2019) pada tikus hipertensi spontan, menunjukkan bahwa pengobatan berkelanjutan dengan EVOO yang mengandung setidaknya senyawa fenolik $17,6 \mathrm{mg} / \mathrm{kg}$ dapat menurunkan biomarker vasokonstriktor dan meningkatkan vasodilatory nitric oxide. Selain itu, penambahan senyawa bioaktif (750 mg / kg senyawa fenolik, terutama hidroksitirosol; 3,4 dihidroksiilglikol, dan oleuropein) dari buah dan daun zaitun juga dapat menyebabkan penurunan hipertensi dan hipertrofi jantung, perbaikan disfungsi endotel, penurunan status oksidatif, serta penurunan kadar kolesterol total plasma pada tikus hipertensi spontan. Hasil yang signifikan pada penurunan tekanan darah sistolik diamati setelah delapan minggu pengobatan dengan minyak zaitun fungsional dibandingkan dengan kelompok kontrol $(\mathrm{p}=0,001)$. Oleh karena itu, penambahan EVOO yang diperkaya ke dalam makanan dapat menjadi alat yang berguna melawan tekanan darah tinggi dan kadar kolesterol plasma, yang merupakan dua faktor risiko penyakit kardiovaskular vazques (2019). Sejalan dengan penelitian sebelumnya, Roberti et al. (2020) juga menemukan efek yang berpengaruh dari pola makan induk tikus yang diperkaya dengan minyak zaitun pada pencegahan peningkatan deposisi matriks ekstraseluler dan peningkatan penanda prooksidan di jantung keturunan tikus diabetes berusia 21 hari $(p<0.001)$ (Roberti et al., 2020).

Sebagian dari efek minyak zaitun yang bermanfaat bagi kesehatan adalah karena kandungannya asam oleat didalamnnya yang ditemukan di semua jenis minyak zaitun, dan sebagian lain disebabkan oleh $>200$ komponen kecil yang terutama mencakup senyawa 
fenolik, tokoferol, fitosterol, karotenoid, luteolin, dan asam triterpenat yang diperkaya dalam EVOO (López-Miranda et al., 2010). Sebagian besar penelitian yang berkaitan dengan konsumsi minyak zaitun terhadap penyakit kardiovaskular tidak membedakan antara jenis minyak zaitun. Namun dalam kohort Spanyol dari studi European Prospective Investigation into Cancer and Nutrition (EPIC) didapatkan penurunan 14\% risiko PJK untuk setiap $10 \mathrm{~g}$ / hari per kenaikan 2.000 kkal di kelompok EVOO, sedangkan konsumsi minyak zaitun biasa tidak didapatka asosiasi. Demikian pula, dalam studi Prevención con Dieta Mediterránea (PREDIMED), penyakit kardiovaskular secara signifikan menurun sebesar 10\% untuk setiap peningkatan $10 \mathrm{~g} /$ hari pada kelompok EVO0, tetapi minyak zaitun biasa tidak berhubungan (Buckland et al., 2012; Guasch-Ferré et al., 2014; Estruch et al., 2020). Bukti lain juga menunjukkan bahwa konsumsi rutin makanan yang kaya akan senyawa fenolik dapat menurunkan risiko perkembangan penyakit kronis. Mekanisme dimana senyawa ini dapat memberikan efek anti inflamasi, khususnya pada penyakit kardiovaskular, melibatkan antara lain aktivitas antioksidan, modifikasi kaskade pensinyalan dan jaringan transkripsi (memblokir pensinyalan dan ekspresi faktor inti kappa B), penurunan adhesi sel imun (limfosit T dan monosit) ke endotel, serta perbaikan disfungsi endotel (de Souza et al., 2017). Daun Olea europaea L. telah digunakan sebagai antihipertensi, aterosklerosis, dan diabetes. Efek anti-hipertensi dan penurun kolesterol dari daun ini diamati dalam studi eksperimental dan klinis. Penurunan tekanan darah telah diamati pada tikus hipertensi spontan yang diberi diet yang diperkaya dengan EVOO selama 12 minggu dibandingkan dengan diet standar. Pemberian berkelanjutan minyak zaitun pomace yang diperkaya asam oleanolat pada tikus hipertensi spontan meningkatkan konduktansi fungsi endotel dan resistensi arteri dengan meningkatkan ekspresi protein endotel oksida nitrat sintase (eNOS). Senyawa minor dari minyak zaitun dan daun zaitun, seperti oleuropein, telah diakui sebagai penyebab akut efek vasodilatasi independen endotelium pada aorta tikus hipertensi spontan Selain itu, asupan berkelanjutan dari ekstrak daun zaitun yang diperkaya oleuropein memberikan efek antihipertensi pada hipertensi genetik dengan meningkatkan fungsi vaskular dan mengurangi status oksidatif dan peradangan di tikus hipertensi spontan. Efek ini terkait dengan penghambatan angiotensin converting enzyme (ACE). Oleh karena itu, senyawa minor minyak zaitun dan turunan zaitun mungkin bertanggung jawab atas efek anti-hipertensi, dan pengayaan VOO dengan senyawa ini dapat meningkatkan sifat perlindungannya (Vazquez et al., 2019). EVOO mengandung komponen yang dapat bertindak sebagai anti oksidan dan anti senyawa hipolipidemia alami yang dapat meningkatkan aktifitas antioksidan enzim hepatik seperti katalase, superoxide dismutase dan glutathion peroxidase. Hydroxytyrosol dan oleuropein dalam minyak zaitun berperan dalam membuang radikal bebas dan menghambat oksidasi low density lipoprotein (LDL). Mekanisme anti hiperkolesterolemia juga dipengaruhi oleh komponen squalen yang menyebabkan berkurangnya aktivitas HMG CoA reduktase dan peningkatan eliminasi kolesterol melalui feses (Hadju et al., 2012). Dalam beberapa studi model hewan dan in vitro disebutkan peran mekanisme aksi senyawa pada minyak zaitun dalam aktivitas peradangan di tingkat kardiovaskular, termasuk efek pada kaskade asam arakidonat dan jalur pensinyalan dan reseptor, peningkatan fungsi vaskular, dan pengurangan molekul adhesi dan kemokin. Pada manusia, efek ini diamati pada tingkat sel (sel kekebalan) dan penanda inflamasi (de Souza et al., 2017). 


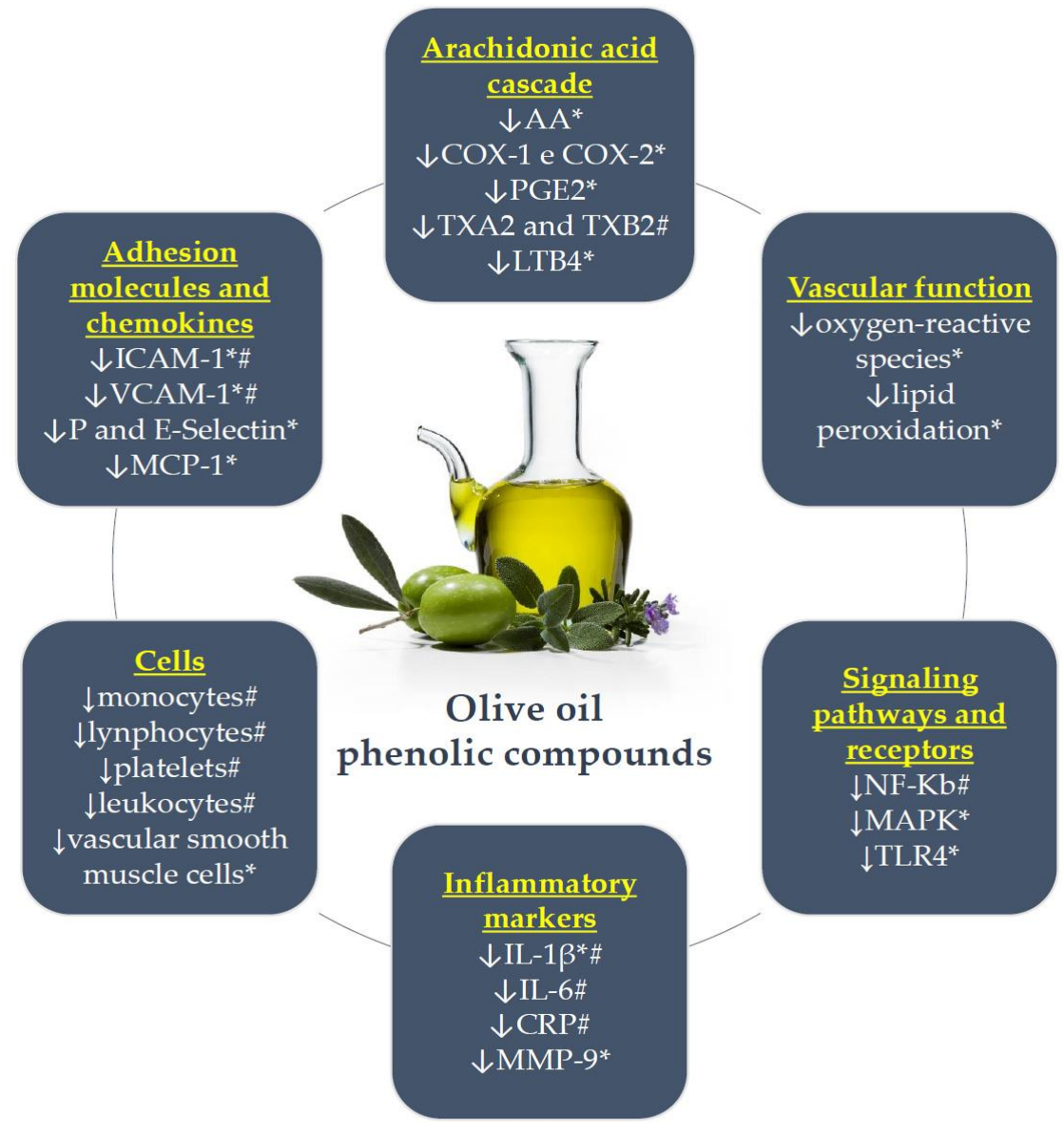

Gambar 1. Efek anti-inflamasi utama dari senyawa fenolik minyak zaitun (de Souza et al., 2017)

Selain itu, keterkaitan diet yang diperkaya minyak zaitun untuk mencegah lingkungan prooksidant / proinflamasi, terdapat hubungan erat pada stres oksidatif, peradangan dan apoptosis. Hal ini dapat dilihat ketika diabetes yang menginduksi apoptosis kardiomiosit, asam oleat mampu untuk melindungi sel otot polos pembuluh darah dari apoptosis yang diinduksi oleh mediator prooksidant / proinflamasi. Karena apoptosis jantung diyakini memainkan peran kausal dalam penyakit jantung sehingga pola makan yang diperkaya minyak zaitun untuk mengurangi apoptosis pada jantung mungkin relevan (Roberti et al., 2020).

\section{Simpulan Dan Saran}

Sebagian dari efek minyak zaitun yang bermanfaat bagi kesehatan adalah karena kandungan asam oleat didalamnnya yang ditemukan di semua jenis minyak zaitun, dan sebagian lain disebabkan oleh $>200$ komponen kecil yang terutama mencakup senyawa fenolik, tokoferol, fitosterol, karotenoid, luteolin, dan asam triterpenat. Sejumlah penelitian telah menunjukkan bahwa asupan minyak zaitun berkaitan dengan sifat antioksidan dan antiplatelet yang berhubungan dengan stres oksidatif, peradangan dan apoptosis. Sehingga diperlukan asupan makanan dengan minyak zaitun secara konsisten untuk memberikan efek kardioprotektif dari berbagai komponen penting didalamnya, sebagai pencegahan penyakit kardiovaskular. 


\section{Daftar Rujukan}

Besnard, G., Khadari, B., Baradat, P., \& Bervillé, A. (2002). Olea europaea (Oleaceae) phylogeography based on chloroplast DNA polymorphism. Theoretical and Applied Genetics, 104(8), 1353-1361. https://doi.org/10.1007/s00122-0010832-x

Buckland, G., Travier, N., Barricarte, A., Ardanaz, E., Moreno-Iribas, C., Sánchez, M. J., Molina-Montes, E., Chirlaque, M. D., Huerta, J. M., Navarro, C., Redondo, M. L., Amiano, P., Dorronsoro, M., Larrañaga, N., \& Gonzalez, C. A. (2012). Olive oil intake and CHD in the European Prospective Investigation into Cancer and Nutrition Spanish cohort. British Journal of Nutrition, 108(11), 2075-2082. https://doi.org/10.1017/S000711451200298X

de Souza, P. A. L., Marcadenti, A., \& Portal, V. L. (2017). Effects of olive oil phenolic compounds on inflammation in the prevention and treatment of coronary artery disease. Nutrients, 9(10). https://doi.org/10.3390/nu9101087

Estruch, R., Lamuela-Raventós, R. M., \& Ros, E. (2020). The Bitter Taste of Extra Virgin Olive Oil for a Sweet Long Life. Journal of the American College of Cardiology, 75(15), 1740-1742. https://doi.org/10.1016/j.jacc.2020.02.043

George, E. S., Marshall, S., Mayr, H. L., Trakman, G. L., Tatucu-Babet, O. A., Lassemillante, A. C. M., Bramley, A., Reddy, A. J., Forsyth, A., Tierney, A. C., Thomas, C. J., Itsiopoulos, C., \& Marx, W. (2019). The effect of high-polyphenol extra virgin olive oil on cardiovascular risk factors: A systematic review and meta-analysis. Critical Reviews in Food Science and Nutrition, 59(17), 2772-2795. https://doi.org/10.1080/10408398.2018.1470491

Guasch-Ferré, M., Hu, F. B., Martínez-González, M. A., Fitó, M., Bulló, M., Estruch, R., Ros, E., Corella, D., Recondo, J., Gómez-Gracia, E., Fiol, M., Lapetra, J., Serra-Majem, L., Muñoz, M. A., Pintó, X., Lamuela-Raventós, R. M., Basora, J., Buil-Cosiales, P., Sorlí, J. V., ... Salas-Salvadó, J. (2014). Olive oil intake and risk of cardiovascular disease and mortality in the PREDIMED Study. BMC Medicine, 12(1), 1-11. https://doi.org/10.1186/1741-7015-12-78

Hadju, V., Handayani., Satriono. (2012). Pengaruh Suplementasi Minyak Zaitun Extra Virgin Terhadap Kolesterol Total dan Trigliserida Subjek Hiperkolesterolemia. Effects of Extra Virgin Olive Oil Suplementation on Total Cholesterol and Triglycerides Hypercholesterolemic Subjects, 1, 1-15.

Kalra, E. K. (2003). Nutraceutical - Definition and introduction. AAPS PharmSci, 5(3), 1-2. https://doi.org/10.1208/ps050325

Loffredo, L., Perri, L., Nocella, C., \& Violi, F. (2017). Antioxidant and antiplatelet activity by polyphenol-rich nutrients: focus on extra virgin olive oil and cocoa. British Journal of Clinical Pharmacology, 83(1), 96-102. https://doi.org/10.1111/bcp.12923

López-Miranda, J., Pérez-Jiménez, F., Ros, E., De Caterina, R., Badimón, L., Covas, M. I., Escrich, E., Ordovás, J. M., Soriguer, F., Abiá, R., Alarcón de la Lastra, C., Battino, M., Corella, D., Chamorro-Quirós, J., Delgado-Lista, J., Giugliano, D., Esposito, K., Estruch, R., Fernandez-Real, J. M., ... Yiannakouris, N. (2010). Olive oil and health: Summary of the II international conference on olive oil and health consensus report, Jaén and Córdoba (Spain) 2008. Nutrition, Metabolism and Cardiovascular Diseases, 20(4), 284-294. https://doi.org/10.1016/j.numecd.2009.12.007

Roberti, S. L., Higa, R., Sato, H., Gomez Ribot, D., Capobianco, E., \& Jawerbaum, A. (2020). Olive oil supplementation prevents extracellular matrix deposition and reduces prooxidant markers and apoptosis in the offspring's heart of diabetic rats. Reproductive Toxicology, 95, 137-147. https://doi.org/10.1016/j.reprotox.2020.05.002 
Rus, A., Molina, F., Martínez-Ramírez, M. J., Aguilar-Ferrándiz, M. E., Carmona, R., \& Moral, M. L. Del. (2020). Effects of olive oil consumption on cardiovascular risk factors in patients with fibromyalgia. Nutrients, 12(4), 1-13. https://doi.org/10.3390/nu12040918

Summerhill, V., Karagodin, V., Grechko, A., Myasoedova, V., \& Orekhov, A. (2018). Vasculoprotective Role of Olive Oil Compounds via Modulation of Oxidative Stress in Atherosclerosis. Frontiers in Cardiovascular Medicine, 5(December), 110.

https://doi.org/10.3389/fcvm.2018.00188

Tejada, S., Pinya, S., Mar Bibiloni, M. del, Tur, J. A., Pons, A., \& Sureda, A. (2016). Cardioprotective Effects of the Polyphenol Hydroxytyrosol from Olive Oil. Current Drug Targets, 18(13), 1477-1486. https://doi.org/10.2174/1389450117666161005150650

Vazquez, A., Sanchez-rodriguez, E., Vargas, F., Jaramillo, S., Carrasco-pancorbo, A., \& Torre, R. De. (2019). Cardioprotective E ff ect of a Virgin Olive Oil Enriched with Bioactive Compounds in.

Widmer, R. J., Flammer, A. J., Lerman, L. O., \& Lerman, A. (2015). The Mediterranean diet, its components, and cardiovascular disease. American Journal of Medicine, 128(3), 229-238. https://doi.org/10.1016/j.amjmed.2014.10.014

Wongwarawipat, T., Papageorgiou, N., Bertsias, D., Siasos, G., \& Tousoulis, D. (2017). Olive Oil-related Anti-inflammatory Effects on Atherosclerosis: Potential Clinical Implications. Endocrine, Metabolic \& Immune Disorders - Drug Targets, 18(1), 5162. https://doi.org/10.2174/1871530317666171116103618

Yubero-Serrano, E. M., Lopez-Moreno, J., Gomez-Delgado, F., \& Lopez-Miranda, J. (2019). Extra virgin olive oil: More than a healthy fat. European Journal of Clinical Nutrition, 72(Table 1), 8-17. https://doi.org/10.1038/s41430-018-0304-x 